\title{
Histomorphology and Histochemistry of the Thyroid and Parathyroid Glands in Sheep - An Overview
}

\author{
K. Rajalakshmi ${ }^{1 *}$, Geetha Ramesh $^{2}$, Usha Kumari ${ }^{2}$ and M. Siva Kumar ${ }^{1}$ \\ ${ }^{1}$ Department of Veterinary Anatomy and Histology, Rajiv Gandhi Institute of Veterinary \\ Education and Research, Kurumbapet, Puducherry-605 009, India \\ ${ }^{2}$ Department of Anatomy, Madras Veterinary College, Chennai-600 007, Tamil Nadu, India \\ *Corresponding author
}

\begin{tabular}{|l|}
\hline K e y w o r d s \\
Histochemistry; \\
$\begin{array}{l}\text { Histomorphology; } \\
\text { Thyroid gland; } \\
\text { Parathyroid gland; Sheep }\end{array}$ \\
\hline Article Info \\
\hline $\begin{array}{l}\text { Accepted: } \\
\text { 17 May 2018 } \\
\text { Available Online: } \\
\text { 10 June 2018 }\end{array}$ \\
\hline
\end{tabular}

A B S T R A C T

A study on the histomorphology and histochemistry of the thyroid and parathyroid glands in sheep was conducted in the prenatal and post natal age groups of sheep. The capsule of the thyroid gland consisted of two layers of connective tissue separated by a layer of adipose tissue. The stroma showed the presence of solitary ganglion cells. The parenchyma of the thyroid gland consisted of solid epithelial cords separated by mesenchymal tissue. In sheep embroys at 25 days of gestation, precursors of $\mathrm{C}$ cells called dark cells were found in the ultimobranchial bodies. Multiple ciliated follicular cells were observed in the developing thyroid of dogs and were prominent at three weeks prior to the expected date of birth. The thyroid follicles were irregular in outline and the diameter increased in the older subjects. In buffaloes, the larger follicles were present in the deeper zone of the thyroid gland. The follicles were lined by follicular cells and light cells. The solid form of colloid was observed in oldest goats. In the sheep thyroid glands, the parafollicular cells (C cells) were oval to polyhedral in shape, frequently possessed long cytoplasmic protrusions and were located mainly in the intrafollicular and often in the parafollicular area. The ultimobranchial follicles of the sheep thyroid were of various shapes, sizes and forms. The ultimobranchial follicles of the sheep thyroid glands were positive for neutral and acid mucopolysaccharides, lipids and acid phosphatase activity. In the golden hamster, the parathyroid was derived from the third pharyngeal pouch, situated on day 13 of gestation on the dorsolateral side of the thyroid, being surrounded by a common capsule with the thyroid. In the parathyroids of the Wister rats, the chief cell clusters were clearly demarcated from the thyroid by a prominent connective tissue capsule with poor vascularity and the cell clusters were separated by an indistinct stroma of connective tissue with occasional fibrocytes. In the sheep parathyroids, the follicles were irregularly distributed in the gland parenchyma and consisted of chief cells, but not of water-clear cells and oxyphil cells. Two types of follicles namely dark and light follicles were observed. In goat, the secretory granules of the chief cells of the internal parathyroids were PAS positive. Chief cells in the parathyroids of duck showed acid and alkaline phosphatase activities. 


\section{Thyroid Gland}

\section{Embryology}

Jordan et al., (1973) found that in sheep embryos at 25 days of gestation, precursors of $\mathrm{C}$ cells called dark cells were found in the ultimobranchial bodies. At 30 days of gestation, they became matured $\mathrm{C}$ cells. After fusion of the ultimobranchial body with the lateral lobe of the thyroid, at about 33 days of gestation, these cells dispersed and formed typical thyroid C cells. Ramji Prasad and Yashwant Singh (1989) observed that in the goat fetus at 45-50 days of gestation the parenchyma of the thyroid gland consisted of solid epithelial cords separated by mesenchymal tissue. Mathur (1971) reported in the Asiatic water buffalo that, the follicles were spherical and small in fetuses. The epithelial cells of the fetuses were cuboidal with round nuclei. Ghannam and Naggar (1973) opined that in the thyroid of buffaloes, aciniwere first observed in the fourth month of fetal life, but acinar differentiation began as early as the third month in the female and was late as the fifth month in the male.

Multiple ciliated follicular cells were observed in the developing thyroid of dogs and were prominent at three weeks prior to the expected date of birth, but became progressively less common as development proceeded and after birth, only rare isolated cilia remained (Nunez and Gershon, 1975). Titlbach et al., (1987) reported that in cat, the C cells of the thyroid appeared on the 38th day of gestation and approximately from the 50th day, got arranged in groups and began to occupy a characteristic position in relation to the follicular epithelium. The largest quantity of $\mathrm{C}$ cells was found in fetuses about to be born. According to Cordier and Haumont (1980), in the nude and NMRI mouse embryos, the ultimobranchial body developed from the fourth endodermal pouch and became entirely incorporated within the thyroid on the 14th day.

\section{Histomorphology}

\section{Capsule and stroma}

Roy et al., (1978 b) described that the main fibro architecture of the thyroid gland in the goat was of collagen and reticular fibres, the latter were being gradually replaced by the former with advancing age. Further, the glandular tissue of the isthmus of the thyroid was gradually replaced by fibrous connective tissue as age advanced. Ashok et al., (1993) recorded the capsular thickness and the quantum of interfollicular connective tissue, which were more in the large ruminants than the small ruminants. Bacha and Wood (1990) in cow and pig and Dellmann (1993) in mammals reported that the thyroid gland was surrounded by a thin capsule of connective tissue and divided into lobules by thin trabaculae. The interstitial loose connective tissue was sparse and contained a dense network of sinusoidal and lymph capillaries.

Further, Bacha and Wood (1990) stated that the connective tissue was abundant in the cow and pig. According to Roy and Yadava (1977) in buffaloes, the capsule of the thyroid gland consisted of two layers of connective tissue separated by a layer of adipose tissue. The stroma showed the presence of solitary ganglion cells. Aughey and Frye (2001) observed that in animals, the thyroid gland was surrounded by a thin capsule of dense irregular connective tissue, which was continuous with the fine reticular fibres of the vascular stroma and was partially divided into lobules by thin trabaculae. Yaswant Singh and Bharadwaj (1982) described that the capsule of the thyroid gland in white leghorn chicken consisted of three layers without inwards namely capsule serosa, capsule adiposa and capsule fibrosa. 
Adhikary et al., (2003) reported that the thyroid gland of prepubertal, pubertal and castrated black Bengal goat, was covered by a three-layered capsule, an outer, the middle and an inner layer. Khaleel and Salih (2017) reported that in sheep the capsule of the thyroid gland was composed of an outer layer of adipose tissue interposed with collagen fibres and an inner dense irregular connective tissue with collagen, elastic fibres and fibroblasts.

\section{Thyroid follicle}

Roy et al., (1978 b) noticed that in goat, the thyroid follicles were irregular in outline and the diameter increased in the older subjects. The follicular epithelium comprised of two types of cells, follicular cells and light cells. The follicular cells had a tendency to become squamous with ageing. The mitotic division was occasional in younger and rare in aged groups. The mode of secretion was merocrine and apocrine. The solid form of colloid was observed in oldest goats. The histomorphological structure of the isthmus was similar to that of the thyroid gland.

Ashok et al., (1993) observed in the small and large ruminants that, in active follicles, the follicular cells were high cuboidal or columnar with a central spheroidal nucleus and a basophilic cytoplasm. In the comparatively less active follicles, the cells were squamous or low cuboidal with clear boundaries. The follicular cells rested on a basement membrane. Mathur (1971) observed that in the Asiatic water buffalo, the follicles were spherical or ovoid and larger in calves and elongated and very large in adults. Depending on the functional phase of the gland, these cells were tall in calves and flat in adults and aged. Some of these different cell types were found in the same follicle. Nuclei of the epithelial cells were round in calves and flat in adults. Roy and Yadava
(1977) found that in buffaloes, the larger follicles were present in the deeper zone of the thyroid gland. The follicles were lined by follicular cells and light cells. Terminal bars, mitotic cell division and degenerative follicular cells were also observed in the epithelium.

Al - Baghdadi (1964) reported that in camel, the follicles of the thyroid gland were irregular in shape, some were elongated and some were tubular. Many of the follicles were branched. The size of the follicles varied by some being many times larger than the other follicles. The differences in the sizes between the regular follicles and the irregular shaped ones with many branches were characteristic of the thyroid gland of the camel.

In piglets, the diameter of the thyroid follicles decreased just after birth, but then began to increase. In stillborn piglets, follicular diameter was similar to that of four day old piglets. (Parker et al., 1980).Tsuchiya et al., (1984) observed that the thyroid follicles in pig were round or oval in shape, the large follicles being more common in the superficial regions of the thyroid gland. Juhl (1981) opined that in addition to the regular thyroid follicles, the second type of follicle ( $\mathrm{S}$ follicle) was observed in the thyroid gland of the young and mature guinea pigs which consisted of an upper, middle and a lower part. The upper part was tubular. The middle part was subdivided into an irregular follicle and a distended follicle. The lower part was tubular in young ones and more follicle like in the mature animals. The thyroid gland of rat showed two types of follicles, those found in the periphery were larger than the central and had small cuboidal cells and a large lumen compared to the central and both types exhibited negligible amounts of colloid material (Maiti, 1980). Dhindsa et al., (1981) described that the thyroid gland of the mice consisted of an aggregation of spherical or 
oval follicles or acini of variable sizes, the interfollicular regions being occupied by a vascularized network of connective tissue.

Adhikary et al., (2003) stated that the thyroid follicles were lined by cuboidal epithelium in prepubertal black Bengal goats, cuboidal to columnar in pubertal group and the follicular epithelium became squamous or flattened in castrated group. He also observed small sized active follicles near the capsule and large sized follicles towards the centre of the gland. Prasanth et al., (2012) observed that in pregnant cat follicles were irregular in shape and smaller in size. Ahmadpanahi and Yousefi (2012) recorded large follicles in the peripheral margin and small follicles in the central part of the thyroid gland in dromedary camel. Igbokwe \& Ezeasor (2015) observed in the prepubertal white crossbred pigs that large follicles were predominantly close to the capsule while medium and small sized follicles were in the central zone.

Khaleel and Salih (2017) reported a homogenous distribution of variable sized follicles in sheep thyroid. Further they recorded a glandular isthmus with different shapes and sizes of follicles, large quantities of interstitial connective tissue and found that each follicle was surrounded by numerous capillaries.

\section{Thyroid colloid}

Bacha and Wood (1990) observed that in the thyroid gland of animals, in an active follicle, the periphery of the colloid adjacent to the apical surface of the follicular cells was vacuolated, while in an inactive follicle, the colloid had a smooth peripheral surface and vacuoles were not present. Dellmann (1993) reported that in animals, the thyroid gland consisted of numerous follicles usually filled with colloid and lined by follicular cells. When resting, the colloid appeared dense and uniformly stained. When stimulated, the colloid was not uniformly stained but often contained peripheral vacuoles. The proportion of active colloid in pigs at the second week of age was lower than during the first week (Studzinski et al., 1979).

Juhl (1981) stated that the colloid-like substance in the distended part of the second kind of follicles ( $\mathrm{S}$ follicles) in guinea pigs appeared more diluted and somewhat granular in contrast to the homogenous more electrondense colloid in the thyroid follicles. Kelly et al., (1984) described that in the human thyroid, the colloid cells of Langendorff were slender cells with pyknotic nuclei and darkly stained cytoplasm that often appeared to be filled with the colloid. They were degenerating cells sloughed off into the lumina of the follicles.

Mohammad Ali et al., (2015) observed diminished colloid and tall columnar epithelial cells in the active thyroid gland of local Iraqiansheeps.

\section{Parafollicular cells}

According to Okada et al., (1990) in the sheep thyroid glands, the parafollicular cells (C cells) were oval to polyhedral in shape, frequently possessed long cytoplasmic protrusions and were located mainly in the intrafollicular and often in the parafollicular area, but were never found touching the follicular lumen. Intrafollicular $\mathrm{C}$ cells were mostly scattered as single elements and often formed chains. Small groups of four to ten C cells occurred predominantly in the parafollicular area. Further he reported that the $\mathrm{C}$ cells were widely distributed in the thyroid gland of sheep, but was limited to the upper two thirds in goat.

Okada et al., (1995) opined that in sheep, the $\mathrm{C}$ cells were not present in either the isthmus 
or in the superior and inferior poles of the thyroid. They were concentrated more in the deep central region of the lobes and decreased gradually towards the periphery. Similarly Nieto and Fdez de Troconiz (1988) also reported that in the sheep, calf, horse, dog and pig, $C$ cells were most numerous in the central region of each lobe of the thyroid gland. Roy et al., (1983) observed that in the caprine thyroid gland, the $\mathrm{C}$ cells were present singly or in groups within the follicle or interfollicular area, but they never lined the follicular cavity. The cytoplasm was rich in basophilic floccular mass and the cytoplasmic granules stained red with Heidenhain's Azan stain. These cells were comparatively lesser in number in younger goats. Ashok et al., (1993) observed in the small and large ruminants that the $\mathrm{C}$ cells were larger with a lightly stained cytoplasm and were found in singles or in groups, located within the basement membrane of the follicular cells as well as in the interfollicular tissue.

Roy and Yadava (1973) stated that, the C cells of the buffalo had a large nucleus with faintly stained cytoplasm and occurred singly or in groups of two or three cells. They were devoid of uniform contour with many shapes and were located among the follicular cells or between these cells and basement membrane. They were separated from direct contact with the colloid. With Mallory and Heidenhain's Azan stain, the secretory granules stained blue and occasionally red. Nuclei were eccentric but regular in outline. Yanai et al., (1982) reported that in equines, $\mathrm{C}$ cells were rare in occurrence and were observed as large and light cells in the follicular wall.

Kameda et al., (1981) observed C cell complexes in dogs, which consisted of a mass of $\mathrm{C}$ cells associated with other epithelial elements and cysts. They were remnants of ultimobranchial bodies, which retained fetal characteristics. Follicular cells in various stages of differentiation were observed in the C cell complexes. Bacha and Wood (1990) reported that in animals, $\mathrm{C}$ cells occurred among the cells that lined the thyroid follicles and also between the follicles. They were larger and had a paler cytoplasm than the follicular cells. Their nuclei were relatively larger and pale. They usually occurred singly but were also in groups. These cells were particularly abundant in dogs. According to Kameda (1988) in dogs and guinea pigs, the C cells were mostly grouped in cell clusters and were located in the inter and parafollicular positions, while in rabbits they appeared as single cells or as a small group of cells localized close to the basal portion of the follicular epithelium. Hurtrel (1974) opined that in cat, the $\mathrm{C}$ cells were distributed uniformly, usually massed together in groups and the cytoplasm contained granulations. The maximum number of $\mathrm{C}$ cells was found in young animals aged less than three months and there was a reduction in the number of Cells with age.

Zabel et al., (1987) observed in rats that, the number of $\mathrm{C}$ cells increased with age and the increase was particularly pronounced in the early postnatal period and after the first year of age. Di Flore (1989) observed that in humans, the $\mathrm{C}$ cells were larger than the follicular cells and were of variable shapes and contained light granular cytoplasm. They did not border directly on the follicular lumina. Yaswantsingh and Bharadwaj (1982) reported that the $\mathrm{C}$ cells were present either at the periphery of the thyroid follicles or in between the follicular cells in white leghorn chicken.

Adhikary et al., (2003) reported that in prepubertal, pubertal and castrated black Bengal goats, the parafollicular or interfollicular cells were arranged singly or grouped within the basal lamina or interfollicular space. Prasanth et al., (2012) 
observed more number of parafollicular cells in pregnant cat than in the non-pregnant one. Igbokwe et al., (2015) encountered parafollicular cells in the basal position between follicular cells in the thyroid glands of adult West African dwarf goat. According to Abdel-Magied et al., (2000), Kausar and Shahid (2006) and Bello et al., (2015) parafollicular $(\mathrm{C})$ cells were not evident in the thyroid gland of the dromedary camels. However Ahmadpanahi and Yousefi (2012) encountered parafollicular cells in the same. Prasanth et al., (2012) recorded in cat the presence of parafollicular cells in between the follicles, arranged as clusters between the follicles.

\section{Ultimobranchial follicles}

Roy and Saigal (1986) stated that the ultimobranchial follicles of the sheep thyroid were of various shapes, sizes and forms. The interfollicular connective tissue was more around the ultimobranchial follicle and formed a thick capsule with a few fat cells. The epithelium of the ultimobranchial follicles was stratified squamous type and the number of cell layers in the epithelium was three or more. At places, the epithelium showed discontinuity where there was an aggregation of epithelial cells rich in light cells. Some of the ultimobranchial follicles showed a sheet of epithelial cells actively engaged in differentiation into small follicles. The ultimobranchial follicles were filled with lightly stained homogenous mass and desquamated cells. The colloid was different from the colloid of normal thyroid follicles. The smaller ultimobranchial follicle had more activity than the larger one.

According to Roy et al., (1978 a), the size and shape of the ultimobranchial follicles in goat, varied from narrow to wide tubular, pearl like, long follicle with colloid, sheet of stratified squamous cells attached to the follicle, bilobed and evaginated with a group of follicles. They were located in the perivascular connective tissue in the deeper zone of the thyroid gland, but their presence in the periphery of the thyroid gland within the capsule was not uncommon. The epithelial lining varied from simple squamous to columnar with or without cilia. The light cells were seen among the epithelial lining. The lumen of the follicles was filled with nucleated, non-nucleated and colloid debris. Harach (1986) observed in the adult humans that, the solid cell nests which were remnants of the ultimobranchial body were located mainly in the middle third of the lateral thyroid lobes and placed along a central to paracentral and slightly dorsal longitudinal axis and were not clearly determined in the early stages of postnatal life.

\section{Histochemistry}

\section{Carbohydrates}

Roy and Saigal (1986) reported that in sheep, the ultimobranchial follicles of the thyroid glands were positive for neutral and acid mucopolysaccharides. In addition, the follicular cells were also positive for neutral and acid mucopolysaccharides, but the $\mathrm{C}$ cells were negative (Roy and Saigal, 1987). Roy et al., (1978a) observed that in the goat thyroid, the lumen of the ultimobranchial follicles contained nucleated, non-nucleated and colloid debris which was PAS positive and the C cells were devoid of PAS positive material (Roy et al., 1983).

Roy and Yadava (1973) found that the C cells in the thyroid gland of buffalo were negative for PAS whereas the follicular cells and colloid were PAS positive (Roy and Yadava, 1977). In dogs and guinea pigs, the colloid like substance in the luminal cavities of the $\mathrm{C}$ cell follicles was PAS positive (Kameda, 1982 and 1986).Dellmann (1993) recorded 
that in animals, the follicular colloid was PAS positive because of its content of glycoprotein (thyroglobulin). Harach (1987) recorded the presence of PAS positive eosinophilic colloid like material in the lumen of the mixed follicles of the thyroids of human beings.

Igbokwe and Ezeasor (2015) observed that in the prepubertal pigs all follicles irrespective of size contained eosinophilic colloid material that was strongly PAS positive.

Nadhim (2017) reported that in the Iraqian goats, the follicular cells and colloid were PAS positive.

\section{Lipids}

Roy and Saigal (1986) recorded that in the sheep, the ultimobranchial follicles of the thyroid gland showed the presence of lipids. In the perinuclear areas of the follicular and parafollicular cells of the thyroid gland of the sheep, the sudanophiliclipid droplets were evenly distributed. The interfollicular connective tissue and the colloid also showed the presence of lipid droplets (Roy and Saigal, 1987). Roy and Yadava (1973) observed that the $\mathrm{C}$ cells of the thyroid of buffalo were negative for lipids. The follicular cells and colloid were also negative for lipids (Roy and Yadava, 1977). Baba (1972) reported that the interstitial lipids were more in the thyroid of the runt piglets.

\section{Enzymes}

Roy and Saigal (1986) observed that in the sheep thyroid glands, the epithelial cells, colloido-cellular debris and connective tissue components of the ultimobranchial follicles were positive for acid and alkaline phosphatases. Fine granular acid phosphatase activity was observed in the interfollicular capillaries, moderate in the supranuclear area of the follicular epithelium and weak in the $\mathrm{C}$ cells and connective tissue cells, but was absent in the colloid. Alkaline phosphatase activity was observed only in the capillaries (Roy and Saigal, 1987). Roy et al., (1993) reported that in the adult castrated male donkeys, the follicular cells were positive for acid and alkaline phosphatase, while the $\mathrm{C}$ cells were negative. Follicular colloid was devoid of all enzymatic activities. Stromal capillaries presented strong alkaline phosphatase activity.

\section{Parathyroid Gland}

\section{Embryology}

Jordan et al., (1975) reported that in the 10 mm (21 days p.c.) sheep embryo, the compact epithelium of the parathyroid III (external parathyroid) was broken into cords of cells by capillaries. In the $12 \mathrm{~mm}$ embryo (25 days p.c.) the parathyroid IV (internal parathyroid) consisted of two or three layers of cells. In the $16 \mathrm{~mm}$ embryo (30 days p.c.) the developing chief cells differed from the adult chief cells only in size, being considerably larger.

In the golden hamster, the parathyroid was derived from the third pharyngeal pouch, situated on day 13 of gestation on the dorsolateral side of the thyroid, being surrounded by a common capsule with the thyroid (Taniguchi et al., 1989). According to Cordier and Haumont (1980) in the nude and NMRI mouse embryos, there was only one pair of parathyroids which developed at about 11.5 days, from a very limited area in the dorsal region of the cranial wall of the third endodermal pharyngeal pouch.

\section{Histomorphology}

\section{Capsule and stroma}

Roy et al., (1984) observed that in goat, the internal parathyroid tissue was embedded in 
the thyroid, either intermingled with the thyroid or isolated by a connective tissue capsule. The connective tissue septae showed reticular fibres which were more conspicuous in younger animals, but were replaced by collagen with advancing age. The interstitial connective tissue increased with advancing age. Trautmann and Fiebiger (1957) and Dellmann (1993) stated that the parathyroid glands of the domestic animals possessed a thin connective tissue capsule, made up of dense irregular connective tissue this was thick in large ruminants and swine and thin in dogs and cats. Trabeculae and interstitial connective tissue were abundant in large ruminants and swine and sparse in other domestic animals. They contained a dense capillary network.

Banks (1993) reported that the capsule of the external parathyroids in animals was areolar connective tissue that blended with the surrounding fascia. The internal parathyroids did not have a capsule perse but were surrounded by the areolar connective tissue of the interstices of the thyroid gland.In the camel, the thin connective tissue capsule of the cranial parathyroid extended into the parenchyma in the form of trabeculae and separated the gland into distinct lobes and lobules. The highly vascular interstitial connective tissue was quite abundant and the connective tissue stroma also contained some fat cells. A frame work of reticular fibres was present in the capsule, trabeculae and in the area surrounding the cells (Nagpal et al., 1989).

Mukerji et al., (1998) reported that in the parathyroids of the Wistar rats, the chief cell clusters were clearly demarcated from the thyroid by a prominent connective tissue capsule with poor vascularity and the cell clusters were separated by an indistinct stroma of connective tissue with occasional fibrocytes. Joshi et al., (1997) observed that the parathyroid glands of the laying and nonlaying white leghorn hens were surrounded by a distinct connective tissue capsule which consisted of collagenous fibres and inactive fibrocytes and a delicate network of reticular fibres was observed between the parenchymal cells. A few glands presented a thick band of trabeculae and fibres associated with large blood vessels.

\section{Parenchyma}

Tsuchiya and Tamate (1981) opined that in the sheep parathyroids, the follicles were irregularly distributed in the gland parenchyma and consisted of chief cells, but not of water-clear cells and oxyphil cells. Two types of follicles namely dark and light follicles were observed. Okada et al., (1990) reported that in sheep, the external parathyroid glands were devoid of $\mathrm{C}$ cells $\mathrm{ln}$ the internal parathyroids, the $\mathrm{C}$ cells were distributed in the periphery and frequently gathered as a large cluster in the central region and were polyhedral or elongate in shape.

Roy et al., (1984) stated that in the internal parathyroid glands of the goat, light and dark chief cells were the main components of the parenchyma. The oxyphilic and syncytial cells were fewer. The secretory granules were few and fine in young animals, but increased and became coarser with advancing age. The oxyphiliccells were few and had intense dark red cytoplasm which occurred in small groups mainly at the periphery or singly throughout the parenchyma. The mast cells were observed in the vicinity of blood vessels and were few in young goats, but were more frequent in animals over 5 years of age.

Tsuchiya (1988) opined that in the internal parathyroid glands of the goat, $\mathrm{C}$ cells were located mainly in the periphery. $\mathrm{C}$ cells were not observed in the external parathyroids. The 
occurrence of the internal parathyroid within the thyroid glands with $\mathrm{C}$ cells in them did not vary with age. Mookkappan and Mariappa (1978) observed that in buffaloes, the parenchyma of the cranial and caudal parathyroids was composed of chief and oxyphil cells. The parenchymal cells showed the presence of cytoplasmic vacuoles. Alveoli lined by columnar cells were seen in the adult but not in young buffaloes. Colloid vesicles lined by a row of cells, cystic vesicles in unilocular and multilocular forms and numerous capillaries were observed throughout the parenchyma.

Tanimura et al., (1985) reported that, in the internal and external parathyroids of equine, the $\mathrm{C}$ cells were distributed not only among the chief cells but also among the clusters of water-clear cells and appeared as a single cell or as a small group of cells and occasionally formed large aggregates. They were more frequent in the parathyroids fused with the thyroids, than in the freed ones. Nagpal et al., (1989) observed in camels that, the parenchyma of the cranial parathyroids consisted of two different cell types namely the principal or chief cells which formed the main mass of the parenchyma and the oxyphilic cells. The chief cells were of two types, the light and dark cells which were arranged in groups, branching and anastamosing cords and also in a follicle-like manner, where the cells usually gathered in a single layer around a sinusoidal capillary. The oxyphilic cells occurred singly or in groups amongst the chief cells.

Capen and Rowland (1968) reported that in the parathyroid glands of the normal rapidly growing kittens (9-22 weeks of age), the active chief cells predominated over the inactive ones and oxyphil cells or transitional forms were not observed. According to Bergdahl and Boquist (1973) in dogs, the parathyroid was composed mainly of light and dark chief cells which occurred in solid sheets with only a slight tendency to follicular arrangement. A few oxyphil cells were seen. Diffusely scattered in the parenchyma, were dense aggregates of syncytial cells and small chief cells and only a few fat cells were encountered among the parenchymal cells. Dellmann (1993) observed that in all domestic mammals except the sheep and goat, the dark and light principal cells were distributed randomly while in sheep and goat, the periphery of the gland was occupied by light cells and in the centre by dark cells.

Aughey and Frye (2001) reported that in animals, the oxyphil cells were large cells with an acidophilic cytoplasm and a pyknotic nucleus. They were found in the horse and large ruminants but were rare in other domestic animals. Bacha and Wood (1990) observed that in chicken, the parenchyma of the parathyroid gland was composed of irregular cords of chief cells, separated by connective tissue and numerous sinusoids. Prasad et al., (1999) reported that the parathyroid glands of the duck consisted of diffuse cords of cells that were elongated, columnar, basophilic, vacuolated and granular with nuclei that were dark in active cells but pale in inactive ones. Prasanth et al., (2012) stated that in cat, the predominant cell type of the parathyroid glands included chief cells or principal cells while oxyphil cells were not identified. Firdous et al., (2013) reported that oxyphil cells were absent in female Kuttanad ducks. Al-Ramadan et al., (2015) distinguished a third cell type in the parathyroids of dromedary camel namely water-clear cell in addition to chief and oxyphil cells.

\section{Associated structures}

According to Edland (1973) in sheep, the parathyroid gland was associated with the pars cervicalis of the thymus similar to that in 
cattle and pigs. In horse, dog, cat, fox and mink which lacked a pars cervicalis of the thymus, the parathyroid was present near the thyroid gland. The goat was exceptional which had a pars cervicalis of the thymus when young, but with the parathyroids near the thyroid gland. Roy et al., (1984) described that in goat, the internal parathyroid tissue was found in association with the ultimobranchial body and the thymic tissue.

\section{Histochem1stry}

\section{Carbohydrates}

Roy et al., (1984) stated that in goat, the secretory granules of the chief cells of the internal parathyroids were PAS positive. Nagpal et al., (1989) reported that in camel, the cytoplasmic granules of the oxyphilic cells of the cranial parathyroids were moderately positive to PAS reaction. Mookappan (1993) recorded that, the capsule of the parathyroids of white Leghorn birds was positive for acid mucopolysaccharides. Prasad et al., (1999) observed that the parathyroid glands of the duck were moderately PAS positive.

\section{Enzymes}

Tsuchiya and Tamate (1980) recorded the activity of alkaline phosphatase in the parathyroids of sheep. Isono and Shoumura (1980) reported that the heterogeneous dense bodies in the chief cells of the parathyroid of rabbit were positive for acid phosphatase. Prasad et al., (1999) recorded the acid and alkaline phosphatase activities in the parathyroids of the duck.

\section{References}

Abdel-Magied, E.M, A.A.M. Taha, and A.B. Abdalla, 2000.Light and Electron Microscopic study of the thyroid gland of the Camel (Camelus dromedarius). Journal Veterinary Medicine. 29(6): 331-336.

Adhikary, G.N., M.A. Quasem and S.K. Das, 2003. Histological observation of thyroid gland at prepubertal, pubertal and castrated black Bengal goat. Pakistan Journal of Biological Sciences 6(11): 998-1004,

Ahmadpanahi, S.J. and M.H. Yousefi, 2012. Anatomical and Histological study on thyroid gland in one humped camel (Camelus dromedarius). Journal of Veterinary Research., 67: 273-278.

Al-Baghdadi, F.A.K., 1964. The Thyroid gland of the camel. Nord. Vet. Med., 16: 1004 -1012. Cited from Vet. Bull., 1977, 47: Abstr. 7432.

Ali. M.A., A.H. Sadoon, A.A.D. A.A.J. Samera and A.A. Sawsan, 2015. Anatomical and Histological study of thyroid gland in local Iraqiansheeps. Journal of International Academic Research for Multidisciplinary. 3(3):195-201.

Al-Ramadan, S.Y., A.M. Ali, M.B. Alzghoul, T.A. Althnian and M.A. Alzayer, 2015. Parathyroid Glands of Dromedary Camel, An Anatomical Study. Conference Paper: June 2015

Ashok, N., C. Vijayaragavan and A. Venkatakrishnan, 1993. Comparative study of the thyroid gland in large and small ruminants. J. Vet. Ani. Sci., 24: 140-146.

Aughey, E. and F.L. Frye, 2001. Comparative Veterinary Histology. Manson Publishing, The Veterinary Press.

Baba, L., 1972. Study of the thyroid in runt piglets. Zentralblatt fur veterinarmedizan, 19A: 44- 51. Cited from Vet. Bull., 1972, 42: Abstr. 4746.

Bacha, W.J. and L.M. Wood, 1990. Color Atlas of Veterinary Histology. Lea \&Febiger, Philadelphia. 
Banks, W.J., 1993. Applied Veterinary Histology, 3rd edn., Mosby Year Book, St.Louis.

Bello, A., B.I. Onyeanusi, M.L. Sonfada, J.B. Adeyanju,M.A. Umaru and J.E. Onu, 2015. A sex related changes of the one humped camel (Camelus dromedarius) thyroid gland: (A Histomorphological study). 1(3):00014.

Bergdahl, L. and L. Boquist, 1973.Parathyroid morphology in normal dogs. Pathologia Europaea, 8: 95-103. Cited from Vet. Bull., 1974, 44: Abstr. 2950.

Capen, C.C. and G.N. Rowland, 1968. The ultrastructure of the parathyroid glands of young cats. Anat.Rec., 162: 327-340.

Cordier, A.C. and S.M.Haumont, 1980. Development of thymus, parathyroids and ultimobranchial bodies in NMRI and Nude mice. Am.J.Anat., 157 : 227 263.

Dellmann, H.D., 1993. Text book of Veterinary Histology. 4th edn., Lea \& Febiger, Philadelphia.

Dhindsa, K.S., R.G. Omran and R. Bhup, 1981. Histological changes in the thyroid gland induced by Monosodium.glutamate in mice. Acta Anat., 109: 97-102.

Di Flore, M.S.H., 1989. Atlas of normal histology. 6th edn., Lea \& Febiger, Philadelphia.

Edland, H., 1973. Parathyroid and thyroid glands and their relationship to parscervicalis of thymus in domestic mammals and fowls. Norsk-VeterinarTidsskrift, 85: 137-145.

Firdous Ahmad Dar, S. Maya, Jose John Chungath, N. Ashok, Harshad Sudhir Patki and K.S. Prashanth Kumar, 2013. Histomorphological study of the parathyroid gland in female Kuttanad ducks (Anasplatyrhynchos domesticus). Veterinary World, 6(11): 941-944.
Ghannam, El. F. and M.A. El Naggar, 1973. Prenatal development and activity of the thyroid gland of the buffalo. Zentralblatt fur veterinarmedizan, 20A: 836-842.

Harach, R.H., 1986. Solid cell Nests of the human thyroid in early stages of postnatal life. Acta Anat., 127: 262-264.

Harach, R.H., 1987. Mixed follicles in the human thyroid gland. Acta Anat., 129: 27-30.

Hurtrel, M., 1974. Topographical identification of Cells of the thyroid gland of cat. Recueil de Medicine Veterinaire, 150: 221-226. Cited from Vet. Bull., 1974, 44: Abst. 4797.

Igbokwe, C.O., D.N. Ezeaser, and M.B. Umar, 2015. Ultrastructure of the thyroid gland in adult West African dwarf goat. (Capra hircus) Int.J.Morphol. 33(2):532-537.

Isono, $\mathrm{H}$. and S. Shoumura, 1980. Effects of vagotomy on the ultrastructure of the parathyroid gland of the rabbit. Acta Anat., 108: 273-280.

Jordan, R.K., B. McFarlane and R,J. Scothorne, 1973. An electron microscopic study of the histogenesis of the ultimobranchial body of the $\mathrm{C}$ - cell system in sheep. J.Anat., 114: 115-136.

Jordan, R.K., B. McFarlane and R.J. Scothorne, 1975. An electron microscopic study of the histogenesis of the parathyroid gland in sheep. J.Ana., 119: 235-254.

Joshi, S., M.L. Mathur and K.S. Deora, 1997. Histological studies on parathyroid gland in laying and nonlaying white leghorn hens (Gallus dornesticus). Indian Vet.J., 9: 81.

Juhl, M., 1981. Morphology of the second kind of follicle in the guinea pig thyroid gland. Acta Anat., 110: 318-326.

Kameda, Y., 1982. Immunohistochemical study of $\mathrm{C}$ cell follicles in dog thyroid glands. Anat. Rec., 204: 55-60. 
Kameda, Y., 1986. Age associated increase of $\mathrm{C}$ cell follicles in guinea pig thyroid glands. Anat. Rec., 216: 175-180.

Kameda, Y., 1988. Ontogeny of Immunoreactive Calcitonin GeneRelated Peptide in thyroid $\mathrm{C}$ cells from dogs, rabbits and guinea pigs. Anat. Rec., 220: 76-86.

Kameda, Y., K. Ikeda and A. Ikeda, 1981. Uptake of Radioiodine in follicles of dog C-cell complexes studied by Autoradiograph and Immunoperoxidase staining. Anat. Rec., 200: 461-470.

Kausar. R and R.U. Shahid, 2006. Gross and Microscopic Anatomy of thyroid gland of one-humped camel (Camelusdromedaries) Pakistan Veterinary Journal., 26(2): 88-90.

Kelly, D.E., R.L. Wood and A.C. Enders, 1984. The endocrine glands. In Bailey's text book of microscopic Anatomy. 18th edn., Williams \& Wilkins, Sydney.

Khaleel. I.M and A.A.M. Salih, 2017. Comparative Histomorphological and Histochemical study of thyroid gland in adult indigenous gazelle (Gazelle Sub gutturosa) and sheep (Ovis aries). Journal of Entomology and zoology studies. 5(6):1236-1241.

Maiti, B.R., 1980. Effect of prolonged treatment of norethisterone (a progestogen only contraceptive) on the thyro-follicular activity of rat. Acta Anat., 107: 307-310.

Mathur, M.L., 1971. Microscopic study of the thyroid gland of the Asiatic water buffalo (Bubalus bubalis). Cited from Vet. Bull., 1971, 41: Abstr. 4417.

Mookkappan, M. and D. Mariappa, 1978. Histological structure of the parathyroid gland of the Indian Buffalo. Indian Vet. J., 55: 190-192.

Mookkappan, M., 1993. Microanatomical studies of parathyroid glands in white leghorn birds. A Ph.D. thesis submitted to TANUVAS, Madras.
Mukerji, B., P.L. Dhande, P.S. Lonkar and K.M. Cherian, 1998. Histological observations on the thyroid and parathyroid of Laboratory rats. Indian. J.Vet.Anat., 10: 53-57.

Nadhim. A.S., (2017). Histological and Histological analysis of thyroid gland in slaughter male local Iraqian goats (Capra Aegagrus). Int.J.Agric.Sc\& Vet.Med., 5(2): 59-66.

Nagpal, S.K., L.S. Sudhakar, Yashwant Singh and L.D. Dhingra, 1989. Histomorphology of the Parathyroid gland of camel. Indian J.Anim. Sci., 59: 80-84.

Nieto, J.M. and P. Fdez.deTroconiz, 1988. $\mathrm{C}$ - cells in the domestic animals. An immunocytochemical, ultrastructural and morphometric study. J. Histochem. Cytochem, 36: 933.

Nunez, E.A. and M.D. Gershon, 1975. Appearance and disappearance of multiple ciliated follicular cells during development of dog's thyroid gland. Anat. Rec., 184: 133-146.

Okada, H., Y. Shigeta and Y. Un-No, 1995. C cell distribution in ovine thyroid gland. Anatomia Histologia Embryologia, 24: 281-284. Cited from Vet. Bull., 1996, 66: Abstr. 4227.

Okada, H.M., K. Matusukawa, N. Ohgiya, H. Yokota, H. Toniyama and A. Yusa, 1990. lummunohistochemical demonstration of parafollicular cells of (C) in sheep thyroid and parathyroid glands. Jap. J. Vet, Sci., 58: 879-882.

Parker, R.O., P.E.V. Williams, F.X. Aherene and B.A. Young, 1980. Histological structure of the thyroid gland in the neonatal pig. Biology of the Neonate, 38: 120-125. Cited from Vet. Bull., 1981, 51: Abstr. 2810.

Prasad, R.V., T.S.C. Rao and C. Vijayaragavan, 1999. Histology and Histochemistry of the parathyroid 
glands of domestic duck. Indian Vet.J., 76: 829-831.

Prasanth, B.A., R.P. Jagapathi, H.S. Patki and

T.S. Chandrasekhara Rao, 2012. Histology of the Thyroid and parathyroid glands of cat. Indian Veterinary Journal., 89(9): 84-85.

Ramji Prasad and Yashwant Singh, 1989. Prefollicular development of the foetal thyroid gland in goat. Indian J. Vet. Anat., 1: 39-43.

Roy, K.S. and R.C.P. Yadava, 1973. Histological and certain histochemicalobservations on light cells of the thyroid gland in Indian buffaloes. Indian J. Anim. Sci., 43: 706-710.

Roy, K.S. and R.C.P. Yadava, 1977. Histological and certain histochemical studies on the thyroid gland of the Indian buffalo (Bubalus bubalis). Indian J. Anim. Sci., 45: 201-208. Cited from Vet. Bull., 1977, 47: Abstr. 5388.

Roy, K.S. and R.P. Saigal, 1986. Histochemical and enzymatic observations on the ultimobranchial follicles of the sheep thyroid. Indian J. Anim. Sci., 56: 1013-1016.

Roy, K.S. and R.P. Saigal, 1987. Histochemical study on thyroid gland of sheep during early pregnancy. Indian J. Anim. Sci., 57: 26-28.

Roy, K.S., H.S. Pawar and Jaswant Singh, 1993. Effect of gonadectomy on thyroid gland of male donkey. Indian J.Vet. Anat., 5: 6-10.

Roy, K.S., R.P. Saigal and B.S. Nanda, 1983. Histomorphological and histochemical studies of parafollicular cells in the thyroid gland of goat. Indian J. Anim. Sci., 53: 287-290.

Roy, K.S., R.P. Saigal and B.S. Nanda, 1984. Histomorphological and histochemicalstudies of internal parathyroid gland of the goat. Indian J. Anim. Sci., 54: 465-468.
Roy, K.S., R.P. Saigal, B.S. Nanda and S.K. Nagpal, 1978 aGross, Histomorphological and Histochemical changes in the thyroid gland of goat with age. II. Occurrence of Ultimobranchial Follicles. Anat. Anz., 143: 72-85.

Roy, K.S., R.P. Saigal, B.S. Nanda and S.K. Nagpal, 1978 b. Gross, Histomorphological and Histochemical changes in the thyroid gland of goat with age. IV. Histomorphological Study. Anat. Anz., 143: 86-95.

Studzinski, T., R. Bobowiec and A. Rybka, 1979. Histomorphological and functional development of thyroid gland in pig during embryonic and postnatal development. Annales Universitatis Mariae Curie SklodowskaSectio DD, 31: 119-126.

Taniguchi, K., Y. Shutoh and S. Mikami, 1989. Immunohistochemical studies on the development of Endocrine cells in the thyroid and parathyroid glands in the golden hamster. Jap.J. Vet. Sci., 52: 19-27.

Tanimura, N., S. Tateyama, D. Nosaka, Y. Moritomo and R.Yamaguchi, 1985. Immunohistochemical and electron microscopical detection of Parafollicular (C) cells in Equine Parathyroid glands. Jap.J. Vet. Sci., 48: 45-52.

Titlbach, M., J. Velicky and H.L Hotova, 1987. Prenatal development of thecat thyroid: Immunohistochemical demonstration of Calcitonin in the $\mathrm{C}$ cells. Cited from Excerpta Medica I, 1998, 42 Abstr. 773.

Trautmann, W.A. and J. Fiebiger, 1957. Fundamentals of the histology of domestic animals. Comstock Publishing Associates, New York.

Tsuchiya and H. Tamate, 1981. Cytochemical Studies on the follicles in sheep parathyroid gland. Tohoku J.Agri.Res., 31: 198-206 
Tsuchiya, T.Y. Shiomura, K. Suzuki, H.Nagai and H. Tamate, 1984. Immunocytochemical study on the C cells in pig thyroid glands. Acta Anat., 120: 138-141.

Tsuchiya, T. and H. Tamate, 1980. Ultrastructural localization of Alkaline phosphatase activity in sheep parathyroid glands. Cited from ExcerptaMedica I, 1981, 35: Abstr. 638.

Tsuchiya, T., 1988. Immunohistochemical study on the $\mathrm{C}$ cells in the internal parathyroid gland of the goat. Jap. J. Zootech.Sci., 59: 49-53.
Yanai, T., S. Tateyama, D. Nosaka and H. Ashizawa, 1982. Some Observations on the Parafollicular (C) cells in the Equine Thyroid. Jap. J. Vet. Sci., 44: 511-516.

Yaswant Singh and Bharadwaj, 1982. Histological and certain histochemical studies on the thyroid gland of the White Leghorn chicken. Indian J. Anim. Sci., 52: 552-556.

Zabel, J. Surdyk and 1.B. Jacek, 1987. Immunocytochemical studies on the thyroid parafollicular cells in postnatal development of the rat. Acta Anat., 130: 251-256.

\section{How to cite this article:}

Rajalakshmi K., Geetha Ramesh, Usha Kumari and Siva Kumar M. 2018. Histomorphology and Histochemistry of the Thyroid and Parathyroid Glands in Sheep - An Overview. Int.J.Curr.Microbiol.App.Sci. 7(06): 1654-1667. doi: https://doi.org/10.20546/ijcmas.2018.706.197 